\title{
Impacts of Solid Waste Disposal on Water Quality of Ugboha River - Esan South West L.G.A, Edo State, Nigeria
}

\author{
Ehichioya, I., Okodugha, D. A. \& Oboh, A.A. \\ Department of Civil Engineering \\ Auchi Polytechnic, Auchi \\ Edo State, Nigeria. \\ Email : abichioya2000@yahoo.co.uk
}

\begin{abstract}
This paper focuses on the impacts of effluent from solid waste disposal on water quality of Ugboha River. This research measured the quality of River water to determine the pollutant concentration, water samples were collected from the river sources for laboratory analysis. The quality parameters considered were the total hardness, dissolved colloid, total solids (TS), turbidity), iron content , temperature total sulphate (TS), $\mathrm{pH}$, and conductivity. Samples were taken from the river source and the magnitudes of pollutant load concentration to the river water were determined for both physical and chemical evaluation. The results indicate that the water quality parameters like total sulphate, magnesium,chloride, iron, and total hardness are found to be high with an average concentration load of $12.0 \mathrm{mg} / \mathrm{l}$, $18.8 \mathrm{mg} / \mathrm{l}, 41 \mathrm{ml}, 2.0 \mathrm{mg} / \mathrm{l}$ and $44 \mathrm{mg} / \mathrm{l}$ respectively. The average concentration for dissolved solid, conductivity, $\mathrm{Ph}$, and turbidity are $0.2 \mathrm{~g}, 119.0 \mu / \mathrm{cm}, 6.20$ and $129 \mathrm{ml}$ respectively. From the samples assessed in this study, the discharge from the river had some elevated concentration for all pollutant except content of iron.
\end{abstract}

Keywords: Effluent, Environment, Ambient Soil, Waste Management \& Leachate

Aims Research Journal Reference Format:

Ehichioya, I., Okodugha, D. A. \& Oboh, A.A. (2018): Impacts of Solid Waste Disposal on Water Quality of Ugboha River Esan South West L.G.A, Edo State, Nigeria. Advances in Multidisciplinary \& Scientific Research Journal. Vol. 4 . No.4. Pp 43-52. Available online at www.aimsjournal.net. - DOI - dx.doi.org/10.22624/AIMS/V4N4P5

\section{INTRODUCTION}

Water is the most essential ingredient that nature provides to sustain life for plants and animals, and also has tremendous role in every mode of human life (Nwankwoala and Nwagbogwu, 2012). Despite its relevance, water is the most poorly managed resource in the world (Fakayode, 2005). The existing tendency of industrialization and urbanization may contribute greatly to the poor quality of water and soil through indiscriminate dumping of solid waste, industrial effluents and other toxic wastes which are the major environmental issues posing threats to the existence of human being (Furtado et al., 1998; Chindah et al., 2004; Ugochukwu, 2004; Emongor et al., 2005). Municipal solid waste normally termed as "garbage" is an inevitable byproduct of human activity which is disposed through dumping. Solid waste land filling is the most common method of solid waste disposal. The landfill sites are open dumpsites, because the open dumpsites are low operating costs and lack of expertise and equipment provided no systems for leachate collections. Open dumps are unsightly, unsanitary, and generally smelly. They attract scavenging animals, rats, insects, pigs and other pests. Surface water percolating through the trash can dissolve out or leach harmful chemicals that are then carried away from the dumpsites in surface or subsurface runoff. Among these chemicals heavy metals are particularly insidious and lead to the phenomenon of bioaccumulation and biomagnifications. These heavy metals may constitute an environmental problem, if the leachate migrates into the ground water. The presence of rivers, bore well at the landfill sites to draw ground water threatens to contaminate the ground water. (Dinesh and Alappat, 2003).

A water pollutant is a chemical or physical substance present in it at the excessive levels capable of causing harm to living organisms. The physical components are the dissolved solids and suspended solids. The chemical parameters are the copper, manganese, lead, cadmium, phosphate, nitrate etc. As the public health concern, the ground water should be free from physical and chemical hazards. The people in and around the dumping site are depending upon the ground water for drinking and other domestic purposes. The soil pollution arises due to the leaching of wastes from dump sites and the most common pollutant involved is the metals like copper, lead, cadmium, mercury etc, The Contamination of ground water and soil is the major environmental risk related to unsanitary land filling of solid waste. The study of Impact of solid waste on water quality of rivers and surrounding areas in Kathmandu, Nepal reveals that the river is heavily polluted' (Devkota et al, 2005). 
In India, water comes from different sources such as rivers lakes, ponds, wells and tube- wells. This water is consumed for a number of purposes namely domestic, industrial utilization, gardening and agricultural irrigation. In all these consumptions the quality of water is a very important since entire economics with respect to water procurement, its treatment and supply depends on the quality of water. In cities and towns water is mainly taken from rivers and other surface water bodies and is supplied to the population after a suitable treatment (Kumar et al, 2005). However, in rural areas, the water needs of people are catered mainly by open and tube wells. These wells are classified as shallow, medium and deep wells and fetch water from aquifers occurring in the geological formation of permeable zones of rocks, sand and gravels.

The quality of ground water mainly depends on the soil strata, through which it percolates and nature of aquifers where it gets stored. The water is becomes unfit for consumption if it gets polluted by one or the other reason. Disposal of solid waste, leachate formation and its subsequent percolation can contaminate the ambient soil and water bodies. The rapid industrialization, urbanization increased rate of population growth, changing life styles and standard of living have put more pressure on water sources to satisfy water consumption requirements of respective areas. Both the quality and quantity of water have become prime concern (chavan and zambare, 2013). To tackle the supply and demand statistics is really a challenging task.

Generally municipal solid waste is collected and dumped in a mixed form in an unscientific manner on open waste land or low lying areas even near rivers, ponds and other ecological sensitive regions, which resulting in the pollution of water whereby the quality of the water deteriorates (Sahu, 2007). The waste dump sites virtually become a breeding ground for all kinds of diseases (Sahu, 2007). Solid waste leachate is the greatest threat to groundwater which possesses various chemical and biological contaminants (Bidhendi et al., 2010).

In present case study the area represents a typical rural community which relies on Ugboha river as their primary sources of water for its day to day needs. In contrast with surface water pollution, ground water pollution is difficult to detect and hard to control. Only some natural processes like wetlands can help to reclaim the water before it gets percolated in ground (shivanand, 2008) and reduce the contamination. Contamination of these heavy metals deteriorates the water quality i.e. change the water properties such as $\mathrm{pH}$, total dissolved solid (TDS), etc. and alter natural processes and natural resource communities, unabated degradation of the aquatic environment poses consequences for fishery resources and their habitats. About $80 \%$ of the diseases in developing countries are related to contaminated water and the resulting death toll is as much as 10 million per year.

\subsection{Problem Definition}

Dump sites are generally known all over the world to pollute the environment either directly or indirectly from their various processes hence water quality assessment is essential to Ugboha river so as to ascertain the level of impact of the solid waste disposal sites effluent periodically discharged to it. As it receives discharged waste water from the sites. Considering implicated certain bacteria species in effluent pollution, not ignoring other processes involved in meet and hide processing, the analysis will deal with certain physiochemical and biological parameter of the river water and soil parameters. Cases of water borne diseases especially typhoid, diarrhea and dysentery has resulted as a result of contact with polluted water. It is therefore expedient to carry out such analysis on the river for awareness purpose, as the users of the river exploit it for economic and recreational purpose without the full knowledge of the danger it may pose to human health.

\subsection{Aim and Objectives}

The project is aimed at gaining a better understanding of the effects of effluent from solid waste disposal sites on ambient soil and quality of water from ugboha river.

The objectives of the research are:

(a) To conducted laboratory analysis on the quality of water in the vicinity of solid waste dumping depots and compared values with WHO standards.

(b) To ascertain if the parameters of water from Ugboha river are in the acceptable limit in accordance with the world Health Organisation( WHO) of Drinking Water Quality Standards.

(c) To profer suitable methods of waste disposal to be undertaken to ensure that it does not affect the environment around the area of disposal or cause health hazards to the people living there. 


\subsection{Scope and Limitation of Work}

The area of this study covers a section of vicinity of Ugboha River around the effluent discharge point. The study is specifically focused on analysis of water quality around the discharge point as defined by some physiochemical and biological parameters. The research is not without limitation as there are bound to be variation in water quality over time due to the continuous flow of the river and other activities. The physical and chemical parameters such as temperature, $\mathrm{pH}$, hardness, electrical conductivity, total dissolved solids, and alkalinity will be studied using various analytical techniques.

\subsection{Relevance of the Work}

The study will be of great benefit to a number of groups in Nigeria. Government agencies especially the Esan South East LGA of Edo State, Nigeria Environmental Protection Agency, rank amongst the top beneficiary of this study Another set of interest group that will benefit from the findings of this research will be the community and society where the dump sites are located, as the study stands to keep them informed.

\section{IMPACTS OF SOLID WASTE ON HEALTH}

The group at risk from the unscientific disposal of solid waste include the population in areas where there is no proper waste disposal method, especially the pre-school children; waste workers; and workers in facilities producing toxic and infectious material. Other high-risk group includes population living close to a waste dump and those, whose water supply has become contaminated either due to waste dumping or leakage from landfill sites. Uncollected solid waste also increases risk of injury, and infection. In particular, organic domestic waste poses a serious threat, since they ferment, creating conditions favourable to the survival and growth of microbial pathogens. Direct handling of solid waste can result in various types of infectious and chronic diseases with the waste workers and the rag pickers being the most vulnerable. Exposure to hazardous waste can affect human health, children being more vulnerable to these pollutants. In fact, direct exposure can lead to diseases through chemical exposure as the release of chemical waste into the environment leads to chemical poisoning. Many studies have been carried out in various parts of the world to establish a connection between health and hazardous waste. Waste from agriculture and industries can also cause serious health risks. Other than this, co-disposal of industrial hazardous waste with municipal waste can expose people to chemical and radioactive hazards. Uncollected solid waste can also obstruct storm water runoff, resulting in the forming of stagnant water bodies that become the breeding ground of disease. Waste dumped near a water source also causes contamination of the water body or the ground water source. Direct dumping of untreated waste in rivers, seas, and lakes results in the accumulation of toxic substances in the food chain through the plants and animals that feed on it.

Disposal of hospital and other medical waste requires special attention since this can create major health hazards. This waste generated from the hospitals, health care centres, medical laboratories, and research centres such as discarded syringe needles, bandages, swabs, plasters, and other types of infectious waste are often disposed with the regular non-infectious waste. Waste treatment and disposal sites can also create health hazards for the neighbourhood. Improperly operated incineration plants cause air pollution and improperly managed and designed landfills attract all types of insects and rodents that spread disease. Ideally these sites should be located at a safe distance from all human settlement. Landfill sites should be well lined and walled to ensure that there is no leakage into the nearby ground water sources. Recycling too carries health risks if proper precautions are not taken. Workers working with waste containing chemical and metals may experience toxic exposure. Disposal of health-care wastes require special attention since it can create major health hazards, such as Hepatitis $B$ and $C$, through wounds caused by discarded syringes. Rag pickers and others who are involved in scavenging in the waste dumps for items that can be recycled may sustain injuries and come into direct contact with these infectious items.

\subsection{Solid Waste Management}

The United States Environmental Protection Agency (USEPA) projects that the annual production of municipal solid waste in India will climb to about 200 million tons by the year 2000 and to 230 million tons by 2010 . These projections have prompted interest in composting municipal solid waste as an alternative to landfills and incineration. Municipal solid waste (MSW) is composted to reduce waste volume and disease-causing organisms, and to cycle nutrients. While municipal solid waste can be converted into compost, the question arises about what to do with the compost once it is produced. Since there are limited markets and few standards on how to utilize municipal solid waste compost on land, only $30 \%$ of all such compost is used for agriculture, landscape, and horticulture, while $70 \%$ of the compost is land filled. Agricultural lands are excellent sites for beneficially using municipal solid waste compost as an organic soil amendment. 
The organic matter present in many soils throughout Minnesota and the U.S. has gradually decreased over the past 100 to 200 years. Most agricultural cropping systems result in the depletion of organic matter. Soil organic matter acts as a sink and source of nutrients in the soil system because it has a high nutrient-holding capacity. It also acts as a large pool for the storage of nitrogen, phosphorus, and sulfur, and has the capacity to supply these and other nutrients for plant growth. Soil organic matter interacts with trace metals, often reducing their toxicity to plants. The physical benefits of organic matter on soil include improved soil structure, increased aeration, reduced bulk density, increased water-holding capacity, enhanced soil aggregation, and reduced soil erosion. The application of municipal solid waste compost to agricultural soil can be a means to return the organic matter to agricultural soil and in some cases reduce the cost of municipal solid waste disposal.

Solid waste may be defined as municipal solid waste resulting from commercial, institutional operations or Industrial solid waste and that generated in effluent treatment facilities. Therefore the term "Solid Waste/ Refuse" encompasses a wide variety of material such as discarded food, paper, plastic, metal, glass and others. These wastes results from diverse societal operations. Such wastes are collected by municipality for disposal in a common treatment facility. In some locations, these wastes are handled along with liquid wastes also (Britoon, 1972). According to Becker (1979), yield was higher in soil amended with municipal solid waste compost compared to soil with no compost, except for the first year on a sandy loam soil. Compost carry-over effect was observed on corn yields three to four years after compost application. On the other hand, annual compost application (40tonnes/acre) resulted in consistent yields for the three years of compost application.

Supplementing the 40 tonnes/acre compost rate with half the Nitrogen needs for corn was sufficient to give optimum yield. Generally, the percent of compost N available to the crop ranged from $5 \%$ to $11 \%$. Deborah (1989) reported that Japanese incinerate 23 percent waste and US $9 \%$. As population wealth, and the ability and willingness to produce disposable packaging and products increase, waste volumes also increase. This generation of waste is expected to continue to increase. Incineration is the fastest growing option in waste disposal management. The disadvantages of incineration include a large amount of money required for construction, the special need for skilled employees and high maintenance of repair costs. Solid waste management in class I cities in India (1999) gives the information about composting process and the various types of composting. It gives the waste management by all means of treatment and has considered corresponding financial aspects (Shekdar et al., 1989).

Solid waste disposal has become a major problem because of the increase in the quantity of waste materials. Water and air pollution can result from poor disposal practice of solid waste. Other types of solid waste like hazardous waste can also become a part of municipal solid wastes. The important aspects of SWM are protection of public health, economical handling, collection, storage and disposal and resource recovery with due consideration to acceptability and conservation (Flintoff, 1976). Giovanni Vallini and Antonio Pera (1988) suggested that the vegetable waste can be composted to green compost. He has given the performance of the composting system adopted together with physico-chemical characteristic of the starting material and the final product. Some microbiological and phytotoxicological details concerning the green compost products is also given municipal solid waste management systems, as they exist in India, consist of collection, transportation and disposal, occasionally with material recovery on processing (Shekdar et al., 1989).

\subsection{Waste Composition}

The organic content is high due to the practice of the common use of fresh vegetables and fruits in the food. The high organic content also necessitates frequent collection and removal of the waste. The paper, glass and plastic content are small; these materials are sold by the citizens to hawkers, who collect and sell them for reuse or recycling. Hence it is only that fraction which does not have a resale value and is in a non usable form, remains in the waste. The waste contains a high percentage of ash and fine earth. This is due to the common practice of depositing street sweepings in community bins. Similarly in many case the surfaces adjoining the roads are uncovered and a large amount of earth materials are swept away and mixed with the waste materials. The calorific value of Indian solid waste varies between $300-500 \mathrm{~kg} / \mathrm{m} 3$ (Bhide and Sundaresan, 1980).

\subsection{Effects on Water Quality}

In addition to affecting plant and animal health, trace elements contained in municipal solid waste composts may be leached (carried by water) from the soil and enter either ground or surface water. As with plant uptake, soil $\mathrm{pH}$, organic matter content, and other soil characteristics affect the amount of leaching. While other data on leaching from municipal solid waste composts is scarce, the evidence from long-term applications of sewage sludge suggests that the rate of leaching is low. Leaching of metals into groundwater is only likely to occur with heavy, repeated applications of municipal solid waste composts over many years in areas with sandy soils or other conditions that limit the opportunity for adsorption of metals by soil (Sinha et al., 1977) 


\section{METHODOLOGY}

A case study with respect to water quality assessment was undertaken at Ugboha village of Esan south East Local Government Area, Ubiajai. This was to ascertain the quality of the river water in the areas of solid waste dumping depots. The village people depend on the river water for their daily water requirement in many parts of the village. A systematic planning was made to sample the water for its quality assessment to insure the impact of solid waste dumping. The Preliminary survey on the quality of water, soil and solid waste samples was conducted, because the water and soil get polluted due to solid waste dumping nearer to the location. The water samples and soil samples were collected. The water samples were collected from the river in the vicinity of solid waste dumping stations and rest were from distant locations. While identifying the location a thought was given to topography of the area, population density and probable sources of contamination etc.

The samples were collected and analyzed for physical and chemical parameters. The physical analysis included tests for turbidity, Total Solids TS), Total Dissolved Solids (TDS) and Total Suspended Solids (TSS). The chemical test included determination of $\mathrm{pH}$ and hardness were as the bacteriological analysis included test for Most Probable Number (MPN), and Standard Plate Count (SPC). The standard methods were used for the present study.

\subsection{Study Area}

The study area was located at Ugboha road, Esan South East Local Government Area of Edo State, Nigeria. This area is geographically a part of Ubiaja which composed of lands which are characterized by high, undulated land surface. The study area is a unique place where solid waste effluents are directly discharged through different channels into the river, and solid wastes are dumped regularly on the bank of the river in an unscientific manner. People, data Collection and its processing became much easier. The village people depend on the river water for their daily water requirement in many parts of the village. A systematic planning was made to sample the river water for its quality assessment to insure the impact of solid waste dumping.

\subsection{Sampling}

The water samples were collected from five different points of the Ugboha River where two samples from upstream, two from downstream and one from the middle point $(\mathrm{M})$ at which the river received solid waste. Samples were collected in 1 litre plastic bottles at a distance of about 100 meters from each other point to analyse $\mathrm{pH}$, electrical conductivity (EC), total dissolved solids (TDS), Sulphate , iron (Fe), total hardness, Temperature and Turbidity. Prior to collect sample, all bottles were washed with distilled water. Before sampling, the bottles were rinsed again three times with the water to be sampled. A $90 \mathrm{ml}$ of water sample from each bottle was transferred to $100 \mathrm{ml}$ plastic bottle which contained $10 \mathrm{ml} 2 \mathrm{M}$ Hydrochloric acid solution for the analysis of heavy metals. The $\mathrm{HCl}$ solution was used to protect water samples from any fungal and other pathogenic attack. After collection, the bottles containing samples were sealed immediately to avoid exposure to air. The samples were taken from the mid-stream and approximately 0.30 meters below the surface. To provide necessary information for each sample such as date of collection, location, time, etc. were recorded in the note book and each sample collected in a plastic bottle was labeled separately with a unique identification number. The water samples for the analysis of were carefully carried to the laboratory of the Department of civil Engineering, Auchi polytechnic, Auchi. In the laboratory, the bottles were kept in a clean, cool and dry place before analyzed.

\subsection{Sample Analysis}

To analyze the physicochemical properties of water, various standard methods were followed and a number of sophisticated instruments were used. Water colour was observed by naked eyes and odor was felt with nose. The water $\mathrm{pH}, \mathrm{EC}$ and TDS were analyzed immediately in the field by using pocket $\mathrm{pH}, \mathrm{EC}$ and TDS meter, respectively. 


\section{RESULTS AND DISCUSSIONS}

In order to achieve the objective of this research program, various laboratory tests were conducted on the water sample. Below is a detailed discussions on the results obtained. The analyses were presented in the tables below.

\subsection{Presentation of Result of Physical Properties}

Table 4.1 TEMPERATURE READINGS

\begin{tabular}{|l|l|l|}
\hline Parameter Test For & Sample Name & result \\
\hline \multirow{4}{*}{ Temperature } & Ugboha River water & 27.9 \\
\cline { 2 - 3 } & & \\
\cline { 2 - 3 } & X borehole water & 30.5 \\
\hline
\end{tabular}

Table 4.2 TASTE READINGS

\begin{tabular}{|c|l|l|}
\hline Parameter Test For & Sample Name & Result (Description Of Test) \\
\hline \multirow{3}{*}{ Taste } & Ugboha River water & Taste clayey [muddy] \\
\cline { 2 - 3 } & X borehole water & Nil \\
\hline
\end{tabular}

TABLE 4.3 COLOUR READING

\begin{tabular}{|l|l|l|}
\hline Parameter Test For & Sample Name & Result Mg/L \\
\hline \multirow{2}{*}{ Colour } & Ugboha River water & 15 \\
\cline { 2 - 3 } & X borehole water & 5 \\
\hline
\end{tabular}

TABLE 4.4 TURBIDITY READING

\section{PARAMETER TEST FOR}

Odour

\section{SAMPLE NAME}

Ugboha River water

$\mathrm{X}$ borehole water
RESULT (LEVEL OF TURBIDITY)

129ML(turbid) $389 \mathrm{NTU}$ (turbid)

$265 \mathrm{ML}$

TABLE 4.5 TOTAL DISSOLVED SOLID (NON - FILTERABLE)

\section{Reading}

\begin{tabular}{|l|l|l|l|l|}
\hline 1 & 2 & 3 & 4 & 5 \\
\hline Parameter tested for & Sample name & Weight of empty & $\begin{array}{l}\text { Weight of Porcelain } \\
+ \text { sample }\end{array}$ & $\begin{array}{l}\text { Weight of sample = } \\
\text { colume 4-3 }\end{array}$ \\
\hline $\begin{array}{l}\text { Total dissolved solid } \\
\text { (TDS) }\end{array}$ & $\begin{array}{l}\text { Ugboha River water } \\
\text { X borehole water }\end{array}$ & $166.7 \mathrm{~g}$ & $\begin{array}{l}265.2 \mathrm{~g} \\
98.5 \mathrm{~g}\end{array}$ & $99.5 \mathrm{~g}$ \\
\hline
\end{tabular}




\subsection{PRESENTATION OF RESULT FOR CHEMICAL PROPERTIES}

Table 4.7 PH VALUES

\begin{tabular}{|l|l|l|}
\hline Parameter Test For & Sample Name & Result Of (Ph) \\
\hline \multirow{3}{*}{$\mathrm{PH}$ value } & Ugboha River water & 6.20 \\
\cline { 2 - 3 } & X borehole water & 3.2 \\
\hline
\end{tabular}

Table 4.8 CHLORIDE READINGS

\begin{tabular}{|l|l|l|l|l|l|}
\hline $\begin{array}{l}\text { Parameter } \\
\text { tested for }\end{array}$ & Sample & $\begin{array}{l}\text { Initial burette } \\
\text { reading }\end{array}$ & $\begin{array}{l}\text { Final burette } \\
\text { reading }\end{array}$ & $\begin{array}{l}\text { Ml Of AG NO3 } \\
\text { Used For } \\
\text { Sample }\end{array}$ & $\begin{array}{l}\text { Chloride }(\mathrm{CL}) \\
\mathrm{mg} / \mathrm{L}\end{array}$ \\
\hline & $\begin{array}{l}\text { Ugboha River } \\
\text { water }\end{array}$ & $50 \mathrm{~mL}$ & $36.5 \mathrm{~mL}$ & $13.5 \mathrm{~mL}$ & $41 \mathrm{~mL}$ \\
\hline Chloride & X borehole water & $50 \mathrm{~mL}$ & $35 \mathrm{~mL}$ & $15 \mathrm{~mL}$ & $56 \mathrm{mgL}$ \\
\hline
\end{tabular}

Table 4.9 TOTAL DISSOLVED SOLID (FILTERABLE)

\begin{tabular}{|l|l|l|l|l|}
\hline 1 & 2 & 3 & 4 & 5 \\
\hline Parameter tested for & Sample name & $\begin{array}{l}\text { Weight of filter } \\
\text { paper }\end{array}$ & $\begin{array}{l}\text { Weight of filter paper } \\
\text { suspended collad }\end{array}$ & $\begin{array}{l}\text { Weight of sample = } \\
\text { colume 4-3 }\end{array}$ \\
\hline $\begin{array}{l}\text { Total dissolved solid } \\
\text { (TDS) }\end{array}$ & $\begin{array}{l}\text { Ugboha River water } \\
\text { X borehole water }\end{array}$ & $1.2 \mathrm{~g}$ & $1.4 \mathrm{~g}$ & $0.2 \mathrm{~g}$ \\
\hline
\end{tabular}

Table 4.10 TOTAL HARDNESS/NON CARBONATE (FOR UNBOILED EDTA SALT) FOR UNBOILED EDTA

\begin{tabular}{|l|l|l|l|l|l|}
\hline Sample name & $\begin{array}{l}\text { Volume } \\
\text { used }\end{array}$ & $\begin{array}{l}\text { Initial burette } \\
\text { reading }\end{array}$ & $\begin{array}{l}\text { Final burette } \\
\text { reading }\end{array}$ & $\begin{array}{l}\text { MI of EDTA } \\
\text { solution used }\end{array}$ & $\begin{array}{l}\text { Hardness } \\
\text { mg/L }\end{array}$ \\
\hline $\begin{array}{l}\text { Ugboha River water } \\
\text { X borehole water } \\
\text { (potable water) }\end{array}$ & $100 \mathrm{ml}$ & $50 \mathrm{ml}$ & $45.6 \mathrm{ml}$ & 4.4 & 44 \\
& $100 \mathrm{ml}$ & $50 \mathrm{ml}$ & 47.4 & 2.6 & 26 \\
\hline
\end{tabular}

Total hardness

$M g / l($ unboiled $)=\underline{\mathrm{ml} \text { of edta used } \times 1000}$

$$
\mathrm{ml} \text { of sample }
$$

Total hardness $=\frac{4.4 \times 1000}{100}=4.4 \mathrm{mg} / \mathrm{l}$

Total hardness $=2.6 \times 1000=26 \mathrm{mg} / \mathrm{l}$

(Auchi poly water) 100 
RANGE OF VALUES FOR IRON AND THEIR COLOUR

\begin{tabular}{|l|l|l|}
\hline S/N & Colour Change & Value Range \\
\hline 1 & Colourless & Nil \\
\hline 2 & Faint pink & $0-$ nil mg/l \\
\hline 3 & Pink & $0.1-0.3 \mathrm{mg} / \mathrm{l}$ \\
\hline 4 & Dark pink & $0.3-0.5 \mathrm{mg} / \mathrm{l}$ \\
\hline 5 & Faint red & $0.5-15 \mathrm{mg} / \mathrm{l}$ \\
\hline 6 & Red & $1.5-3.0 \mathrm{mg} / \mathrm{l}$ \\
\hline 7 & Dark red & Above $3 \mathrm{mg} / \mathrm{l}$ \\
\hline
\end{tabular}

\begin{tabular}{|l|l|l|l|}
\hline Parameter Test For & Sample Name & Colour & $\begin{array}{l}\text { Range Of Value For Color } \\
\text { Change }\end{array}$ \\
\hline \multirow{3}{*}{ Iron } & Ugboha River water & Red & $1.5-3.0 \mathrm{mg} / \mathrm{l}$ \\
& X borehole water (potable) & Dark red & $3 \mathrm{mg} / \mathrm{l}$ \\
\hline
\end{tabular}

\begin{tabular}{|l|l|l|l|l|l|}
\hline Parameter Tested For & $\begin{array}{l}\text { Sample } \\
\text { name }\end{array}$ & $\begin{array}{l}\text { Initial burette } \\
\text { reading }\end{array}$ & $\begin{array}{l}\text { Final burette } \\
\text { reading }\end{array}$ & Ml of EDTA used & $\begin{array}{l}\text { Mg 2x present } \\
\text { (mg/l) }\end{array}$ \\
\hline Magnesium & $\begin{array}{l}\text { Ugboha } \\
\text { River } \\
\text { water }\end{array}$ & $50 \mathrm{ml}$ & $28 . \mathrm{ml}$ & $21.6 \mathrm{ml}$ & 18.8 \\
& $\begin{array}{l}\text { X borehole } \\
\text { water }\end{array}$ & $50 \mathrm{ml}$ & $36 . \mathrm{ml}$ & $14 \mathrm{ml}$ & 12.7 \\
\hline
\end{tabular}

TABLE 4.12 CONDUCTIVITY RESULTS

\begin{tabular}{|l|l|l|}
\hline Parameter Test For & Sample Name & Conductivity $\mathbf{~ m s} / \mathbf{c m}$ \\
\hline Conductivity & Ugboha River water & 119.0 \\
& & 116.7 \\
\hline
\end{tabular}

TABLE 4.13 SULPATE RESULTS

\begin{tabular}{|l|l|l|l|}
\hline $\begin{array}{l}\text { PARAMETER TEST } \\
\text { FOR }\end{array}$ & SAMPLE NAME & $\begin{array}{l}\text { SULPATE } \\
\text { RANGE }\end{array}$ & INFERENCE \\
\hline Sulphate & Ugboha River water & $0-12 \mathrm{mg} / \mathrm{l}$ & Opacity (opaque) Sulphate present \\
& X borehole water & 0 & Not opaque (no Sulphate) \\
\hline
\end{tabular}




\section{CONCLUSION AND RECOMMENDATIONS}

\subsection{Conclusions}

At the household level, proper segregation of waste has to be done and it should be ensured that all organic matter is kept aside for composting, which is undoubtedly the best method for the correct disposal of this segment of the waste. In fact, the organic part of the waste that is generated decomposes more easily, attracts insects and causes disease. Organic waste can be composted and then used as a fertilizer.

\subsection{Recommendations}

The following reccomendayions are madebased on the findimgs from the research:

i) Proper methods of waste disposal have to be undertaken to ensure that it does not affect the environment around the area or cause health hazards to the people living there..

ii) The results suggested that the solid waste and effluents being discharged into the river have considerable negative effects on the water quality of the river water and as such, the water was not very good for human purposes and for other uses.

iii) Only feasible options that could be followed such as appropriate distance from the surrounding water body should be maintained for waste dumping and dumping site should be properly managed.

\section{REFERENCES}

1. Chavan B. L. and Zambare N. S,( 2013), Int. J. of Research in Civil Engineering, Architecture \& Design,1(2) 46-53

2. Dinesh Kumar., and B.J. Alappat,(2003) Monitoring Leachate Compoisiton at a municipal landfill site in New Delhi, India, Int. J. Environment and Pollution., 19(5), 454-465 .

3. Dinesh, C. Devkota and K.Watanabe.,(2005) Impact of solid waste on water quality of Bishnumati river and surrounding areas in Kathmandu, Nepal, J. Nepal Chem. Soc., 31, 19-24

4. Emongor, V.; Kealotswe, E. Koorapetse, I. ; Sankwasa, S. and S. Keikanetswe, S. (2005). Pollution indicators in Gaberone effluent. Journal of Applied Science, 5: 147-150.

5. Fakayode, S. O. (2005). Impact of industrial effluents on water quality of the receiving Alaro River in Ibadan Nigeria. Ajeam-Ragee, 10: 1-13.

6. Furtado, A. A. L.; Albuquerque, R. T.; Leite, S. G. F. and Pecanha, R. P.(1998). Effect of hydraulic retention time on nitrification in an airlift biological reactor. Brazilian Journal of Chemical Engineering, 15: 1-7.

7. Islam, M. S. and Tanaka, M. (2004). Impacts of pollution on coastal and marine ecosystems including coastal and marine fisheries and approach for management: A review and synthesis. Marine Pollution Bulletin, 48(7-8): 624-649.

8. Islam, M. S. and Tanaka, M. (2004). Impacts of pollution on coastal and marine ecosystems including coastal and marine fisheries and approach for management: A review and synthesis. Marine Pollution Bulletin, 48(7-8): 624-649. Potential of natural bed soil in adsorption of heavy metals in industrial waste landfill. International Journal of Environmental Science and Technology, 7(3): 545-552.

9. Mukherjee, S. and Nelliyat, P. (2006). Groundwater pollution and emerging environmental challenges of industrial effluent irrigation: A case study of Mettupalayam Taluk, Tamilnadu, India. In: IWMI-TATA Water Policy Program's 5th Annual Partners' Research Meeting.

10. Nwankwoala, H. O. and Nwagbogwu, C. N. (2012). Characteristics and quality assessment of groundwater in parts of Akure, South-Western Nigeria. Journal of Environmental Science and Water Resources, 1(4): 6773.

11. Rahman, M. M.; Sultana, K. R. and Hoque, M. A. (2008). Suitability sites for urban solid waste disposal using GIS approach in Khulna city, Bangladesh. Proc. Pakistan Acad. Sci., 45(1): 11-22.

12. Sahu, A. K. (2007). Present scenario of municipal solid waste dumping grounds in India. In: Proceedings of the international conference on sustainable solid waste management, pp. 327-333.

13. Satter, M. A. and Islam, M. S. (2005). Quality assessment of river water around Dhaka city. Bangladesh Journal of Environmental Science, 10: 326-32 
Advances In Multidisciplinary

Alivs \& Scientitie Research

APPENDEX

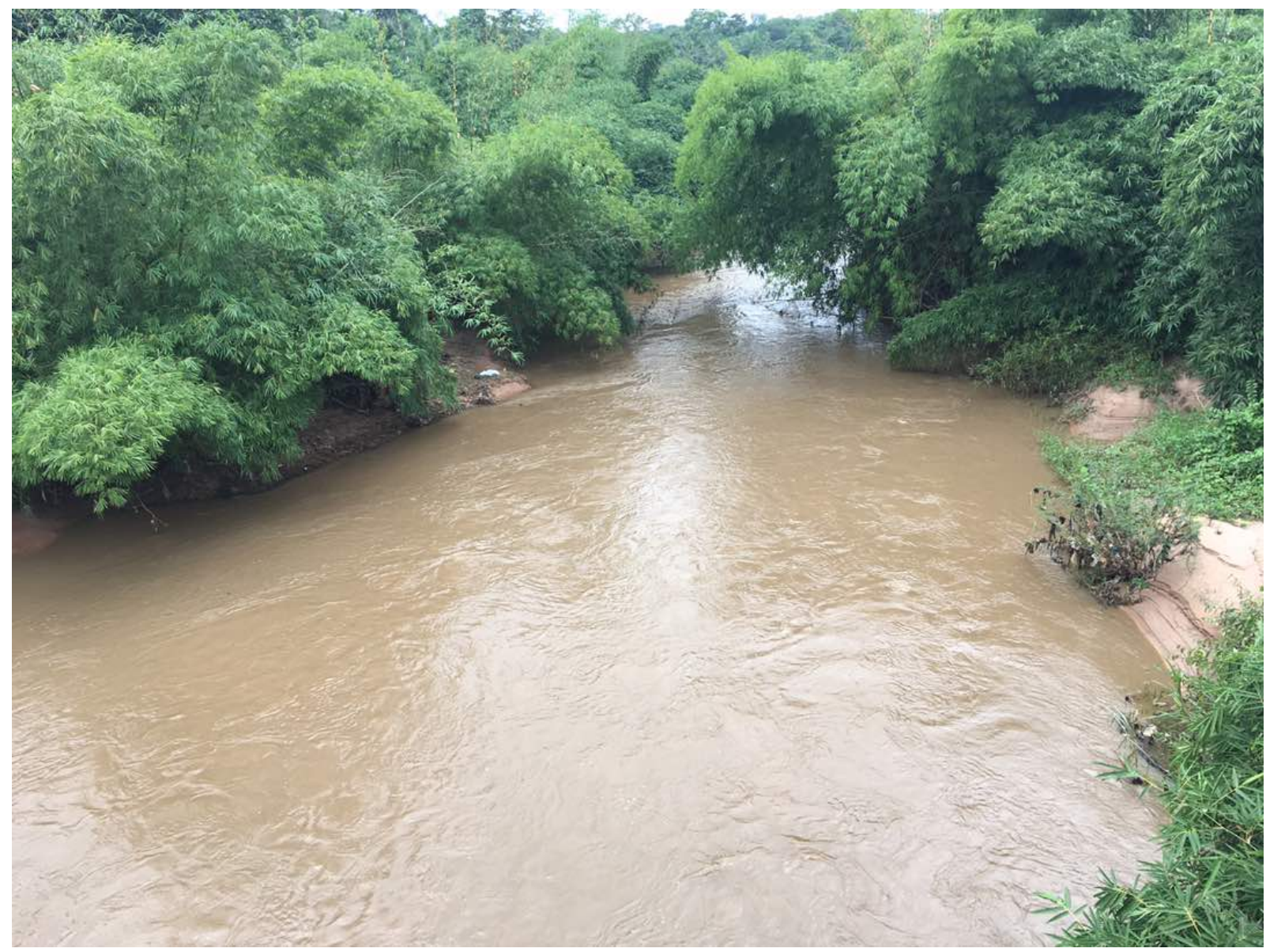

Plate 1: A section of Ugboha River 